\title{
МОРФОЛОГІЧНИЙ СКЛАД ТА М'ЯСО-САЛЬНІ ЯКОСТІ ТУШ СВИНЕЙ
}

Бірта Габріелла Олександрівна доктор сільськогосподарських наук, професор Вищий навчальний заклад Укоопспілки «Полтавський університет економіки і торгівлі» ORCID: 0000-0001-6952-7554

E-mail: birta2805@gmail.com

Бургу Юрій Георгійович кандидат сільськогосподарських наук, доцент Вищий навчальний заклад Укоопспілки «Полтавський університет економіки і торгівлі» ORCID: 0000-0003-0560-1203 E-mail: byrgy1973@gmail.com

Флока Людмила Валеріївна кандидат сільськогосподарських наук Вищий навчальний заклад Укоопспілки «Полтавський університет економіки і торгівлі» ORCID: 0000-0001-5429-2924 E-mail: flokaliudmyla@gmail.com

Хмельницька Євгенія Вікторівна кандидат технічних наук, доцент Вищий навчальний заклад Укоопспілки «Полтавський університет економіки і торгівлі» ORCID: 0000-0002-2513-3032 E-mail: evghme37112@gmail.com

Рачинська Зоя Павлівна старший викладач Вищий навчальний заклад Укоопспілки «Полтавський університет економіки і торгівлі»

ORCID: 0000-0002-4210-7119 E-mail: zojar87@gmail.com

Досліджувалась м'ясність туш при різних рівнях годівлі свиней великої білої, миргородської, ландрас, полтавської м'ясної, червоної білопоясної порід. Морфологічний склад туш вивчали шляхом обвалки правої напівтуші. Масу м'язової тканини визначали за різницею між масою напівтуші і сумарною масою сала та кісток. Площу «м'язового вічка» вимірювали на поперековому розрізі найдовшого м'яза спини, між останнім грудним і першим поперековим хребиями методом копіювання «малюнку зрубу» на кальку та вимірювання його за допомогою планіметра. Результати обвалки туш піддослідних свідчать, що морфологічний склад туші залежить від породних особливостей тварин. При середньодобових приростах 250-350 г за рахунок низьких приростів і, як правило, більшого при иьому осалення, вихід м'яса у тварин всіх піддослідних груп був низьким. При цьому найбільший вихід м'яса мали тварини червоної білопоясної породи: при забої в 100 ке - 50,6 \%, при забої в 125 ке - 48,9 \%. При збільшенні забійної маси до 125 кг питома маса кісток в тушах зменшувалась в усіх піддослідних групах на 0,3-0,6 \%. Відмічалось зменшення відношення сала до м'яса в межах 0,46-0,61 при забої в 100 ке і 0,49-0,70 - в 125ке. Збільшення середньодобових приростів на відгодівлі до 800-1000 г сприяло збільшенню виходу м'яса в тушах в порівнянні з тушами свиней середнього рівня годівлі. Різниця між тушами свиней в 100 кг дорівнювала 1,1-1,7%; при збільшенні забійної маси різниця склала 1,4-2,1 \%. Найвищою енергетичною цінністю характеризувалося м'ясо тварин м'ясо-сальних і сальних генотипів (I ma II групи). При типовому рівні відгодівлі калорійність їх м'яса становила в середньому 134,9-135,8 ккал при забої у 100 кг і 141,5-144,2 ккал - у 125 ке, що відповідно на 8,1-9,0 та 11,113,8 ккал більше в порівнянні з представниками породи ландрас, де цей показник був найменшим. При збільшенні середньодобових приростів спостерігалось зменшення калорійності м'яса. Найменшою вона спостерігалась у свиней, вирощених при інтенсивному рівні відгодівлі. Отже, при середньодобових приростах 250-350 г за рахунок низьких приростів $і$, як правило, більшого при цьому осалення, вихід м'яса у тварин всіх піддослідних груп був низьким. Збільшення середньодобових приростів на відгодівлі до 800-1000 г сприяло збільшенню виходу м'яса в тушах порівняно з тушами свиней, вирощених при оптимальних умовах. Різниця між тушами свиней в 100 ке дорівнювала 1,1-1,7%; при збільшенні забійної маси різниця склала 1,4-2,1\%. Дисперсійний аналіз впливу рівня годівлі на вміст м'яса в тушах показав, що коефіцієнт детермі- 
нації, тобто питома вага фракторіальної дисперсії

Ключові слова: порода, м'ясо, сало, кістки, рівень годівлі, середньодобовий приріст, забійна маса, туша, вихід м'яса.

DOI: https://doi.org/10.32845/bsnau.Ivst.2020.4.4

У сучасних умовах інтенсивного ведення тваринництва велике значення надається впровадженню інтенсивних технологій при виробництві м'яса. Особлива роль у вирішенні м'ясної проблеми відводиться свинарству.

В даний час в сільському господарстві свині $€$ головними тваринами, що вирощуються на м'ясо, так як саме в свинях вдало поєднуються ряд корисних і зручних для вирощування ознак [1].

Повноцінна годівля $€$ необхідною умовою підвищення індивідуальної продуктивності сільськогосподарських тварин, а остання визначає зоотехнічну та економічну ефективність ведення тваринництва.

Потреба тварин у протеїні залежить в першу чергу від їх віку. Виділяють наступні періоди у вирощуванні і відгодівлі свиней, що пов'язані 3 інтенсивністю розвитку їх м'язових волокном: швидкого росту (приблизно до 80 днів), коли волокна найдовшого м'яза спини збільшуються більше ніж на $50 \%$, що здійснюється в основному за рахунок розвитку м'язової тканини; перехідний (80-120 днів), характерний сталістю відкладання білка в тілі, уповільнення росту м'язових волокон і підвищення інтенсивності процесів жироутворення; ожиріння, коли ріст м'язових волокон на $75 \%$ закінчений, відносний вміст білка в тілі починає падати, а кількість жиру збільшується майже прямолінійно [10].

Слід також відмітити, що здатність утворення м'язових тканин, а також потреба тварин в протеїні тісно зв'язана з їх спадковими задатками: при рівних умовах годівлі і утримання тварини м'ясних порід більш інтенсивно синтезують білок, ніж сальних і напівсальних [8].

Підвищення м'ясності туш свиней шляхом спрямованої годівлі широко використовується в практиці свинарства. Але не слід забувати, що вміст м'яса в туші залежить також від факторів, що належать до спадковості (порода або породність, племінні якості та ін.) [9].

При нормальних умовах годівлі, утримання і підбору порід, типів та ліній, що добре поєднуються, помісі відрізняються підвищеною життєздатністю, кращим засвоєнням корму, інтенсивнішим ростом і розвитком, високою відтворювальною здатністю і більш високою стійкістю до різних захворювань. Ефект від схрещування в середньому складає по приросту маси 10-15 \% і по оплаті корму 8-10 відсотків [6].

Але в умовах недостатньої годівлі, за окремими даними, помісні тварин (ВБ х Л) знижували прирости на 24,5 $\%$, тоді як чистопородні тварини (ВБ) лише на $15,7 \%$.

Значним резервом збільшення виробництва свинини $€$ підвищена передзабійна маса тварин. Однак, залишається до кінця не вирішеним питання про оптимальні кондиції свиней для забою. Результати росту досліджень показали, що відгодівля свиней до великих кондицій (120-130 кг) приводять до збільшення затрат корму на одиницю приросту і підвищення собівартості продукції [7].

Збільшення кінцевої живої маси при відгодівлі від 100 до 125 кг та особливо до 150 кг супроводжується природним подовженням часу і помітним зростанням кормових витрат та інших засобів на одиницю приросту. Більш м'ясні туші можна одержати від помісей, батьківські форми яких є м'ясні генотипи, при відгодівлі до 100-125 кг, більш жирні до 150 кг [5].

Підвищення забійної маси свиней до 110-120 кг дозволяє збільшити виробництво свинини в переліку на одну матку і знизити її собівартість. Забій свиней при більш низьких вагових кондиціях сприяє зниженню кормових затрат і збільшенню виробництва м'ясних туш. Економічно це більш виправдано, особливо при інтенсивних технологіях відтворення молодняку. Одночасно, з збільшенням живої маси свиней при забої від 100 до 140 кг відносна кількість м'яса в тушах знижується з 55,9 до 51,0 \%, а кількість жиру збільшується 3 27,4 до 33,5 \%. При цьому доля високоякісних м'ясних частин в тушах зменшується до $42,1 \%$, що суттєво впливає на їх класність і ціну на свинину. Фізико-хімічні дослідження якості м'яса і сала свиней з урахуванням віку свідчать про збільшення відсотку внутрішньом'язового жиру і сухої речовини в м'ясі, підвищення вмісту вологи і поліненасичених кислот в салі [4].

За даними публікацій відзначено, що в тушах свиней м'ясних генотипів осалювання починається в більш пізньому віці, ніж у тварин універсальних та сальних порід. У тушах цих свиней при відгодівлі до високих вагових кондицій на 10 \% більше міститься м'яса і на стільки ж менше сала в порівнянні з тушами універсальних порід, а зниження виходу цінних частин туші у них проходить тільки при відгодівлі до живої маси 140 кг, що дає підставу вважати таку відгодівлю перспективною. Помісний молодняк, батьківською формою якого є м'ясні породи, доцільно відгодовувати до живої маси 120-130 кг, так як затрати кормів за цей період зростають в незначній мірі.Таким чином, лише за достатньої годівлі можна домогтись помітного підвищення продуктивності чистопородних та помісних тварин, високого приросту живої маси, якості одержуваної продукції та зниження витрат кормів на відгодівлі [11].

Метою досліджень було вивчення м'ясності туш при різних рівнях годівлі свиней великої білої (І група), миргородської (II група), ландрас (III група), полтавської м'ясної (IV група), червоної білопоясної (V група).

Матеріали та методи досліджень. Морфологічний склад туш вивчали шляхом обвалки правої напівтуші. Масу м'язової тканини визначали за різницею між масою напівтуші і сумарною масою сала та кісток. Площу «м'язового вічка» вимірювали на поперековому розрізі найдовшого м'яза спини, між останнім грудним і першим поперековим хребцями методом копіювання «малюнку зрубу» на кальку та вимірювання його за допомогою планіметра.

Результати дослідження та обговорення. Результати обвалки туш піддослідних свиней свідчать, що морфологічний склад туші залежить від породних особливостей тварин (таблиця 1, 2, 3) При середньодобових приростах 250-350 г за рахунок низьких приростів і, як правило, більшого при цьому осалення, вихід м'яса у тварин всіх піддослідних груп був низьким. 
Морфологічний склад туш піддослідних свиней

Таблиця 1

(середньодобовий приріст 250-350 г, n=15)

\begin{tabular}{|c|c|c|c|c|c|c|c|c|c|c|c|c|c|c|c|}
\hline \multirow{4}{*}{ 哥 } & \multirow{4}{*}{$\begin{array}{l}\text { 흥 } \\
\text { 응 }\end{array}$} & \multicolumn{12}{|c|}{ Міститься в туші, \% } & \multirow{2}{*}{\multicolumn{2}{|c|}{$\begin{array}{c}\text { Співвідношення сала } \\
\text { до м'яса }\end{array}$}} \\
\hline & & \multicolumn{4}{|c|}{ М'ясо } & \multicolumn{4}{|c|}{ Сало } & \multicolumn{4}{|c|}{ Кістки } & & \\
\hline & & \multicolumn{2}{|c|}{$100 \mathrm{k \Gamma}$} & \multicolumn{2}{|c|}{$125 \mathrm{kг}$} & \multicolumn{2}{|c|}{$100 \mathrm{kг}$} & \multicolumn{2}{|c|}{$125 \mathrm{kr}$} & \multicolumn{2}{|c|}{100 кг } & \multicolumn{2}{|c|}{$125 \mathrm{kr}$} & $100 \mathrm{kг}$ & $125 \mathrm{k \Gamma}$ \\
\hline & & $\mathrm{K \Gamma}$ & $\%$ & $\mathrm{~K} \Gamma$ & $\%$ & $\mathrm{~K} \Gamma$ & $\%$ & $\mathrm{~K} \Gamma$ & $\%$ & $\mathrm{K \Gamma}$ & $\%$ & $\mathrm{K \Gamma}$ & $\%$ & & \\
\hline I & BБ & $\begin{array}{c}33,8 \pm \\
0,66\end{array}$ & 48,9 & $\begin{array}{c}40,6 \pm \\
0,62\end{array}$ & 46,3 & $\begin{array}{c}27,1 \pm \\
0,55\end{array}$ & 39,2 & $\begin{array}{c}37,1 \pm \\
0,64\end{array}$ & 42,3 & $\begin{array}{l}8,2 \pm \\
0,52\end{array}$ & 11,9 & $\begin{array}{c}10,0 \pm \\
0,62\end{array}$ & 11,4 & $\begin{array}{c}0,80 \pm \\
0,16\end{array}$ & $\begin{array}{c}0,91 \pm \\
0,22\end{array}$ \\
\hline II & $M$ & $\begin{array}{c}32,4 \pm \\
0,94\end{array}$ & 47,3 & $\begin{array}{c}39,8 \pm \\
0,29\end{array}$ & 45,8 & $\begin{array}{c}28,2^{*} \pm \\
0,48\end{array}$ & 41,2 & $\begin{array}{c}37,6^{*} \pm \\
0,33\end{array}$ & 43,3 & $\begin{array}{l}7,9 \pm \\
0,23\end{array}$ & 11,5 & $\begin{array}{l}9,5 \pm \\
0,49\end{array}$ & 10,9 & $\begin{array}{c}0,87 \pm \\
0,22\end{array}$ & $\begin{array}{c}0,95 \pm \\
0,31\end{array}$ \\
\hline III & ת & $\begin{array}{c}35,6^{\star *} \pm \\
0,84\end{array}$ & 50,1 & $\begin{array}{c}43,9^{*} \pm \\
0,84\end{array}$ & 48,6 & $\begin{array}{c}27,2 \pm \\
0,66\end{array}$ & 38,3 & $\begin{array}{c}36,3 \pm \\
0,51\end{array}$ & 40,1 & $\begin{array}{l}8,2 \pm \\
0,45\end{array}$ & 11,6 & $\begin{array}{c}10,2 \pm \\
0,39\end{array}$ & 11,3 & $\begin{array}{c}0,76 \pm \\
0,18\end{array}$ & $\begin{array}{c}0,83 \pm \\
0,19\end{array}$ \\
\hline IV & ПМ & $\begin{array}{c}35,1^{*} \pm \\
0,29\end{array}$ & 48,7 & $\begin{array}{c}42,7 \pm \\
0,62\end{array}$ & 47,1 & $\begin{array}{c}28,5 \pm \\
0,19\end{array}$ & 39,5 & $\begin{array}{c}37,9 \pm \\
0,24\end{array}$ & 41,8 & $\begin{array}{c}8,5^{\star *} \pm \\
0,62\end{array}$ & 11,8 & $\begin{array}{c}10,1 \pm \\
0,62\end{array}$ & 11,1 & $\begin{array}{c}0,81 \pm \\
0,31\end{array}$ & $\begin{array}{c}0,89 \pm \\
0,24\end{array}$ \\
\hline V & ЧБП & $\begin{array}{c}36,0^{* *} \pm \\
0,75\end{array}$ & 50,6 & $\begin{array}{c}43,8^{\star \star} \pm \\
0,99\end{array}$ & 48,9 & $\begin{array}{c}26,8 \pm \\
0,45\end{array}$ & 37,7 & $\begin{array}{c}35,6 \pm \\
0,29\end{array}$ & 39,8 & $\begin{array}{l}8,3 \pm \\
0,59\end{array}$ & 11,7 & $\begin{array}{c}10,1 \pm \\
0,81 \\
\end{array}$ & 11,3 & $\begin{array}{c}0,75 \pm \\
0,42 \\
\end{array}$ & $\begin{array}{c}0,81 \pm \\
0,33 \\
\end{array}$ \\
\hline
\end{tabular}

При цьому найбільший вихід м'яса мали тварини червоної білопоясної породи: при забої в 100 кг - 50,6 \%, при забої в 125 кг - 48,9 \%.

В порівнянні з миргородською породою, де цей показник був найменшим різниця склала 3,3-3,1\%. Натомість, сала в тушах найбільше містилось у свиней саме миргородської і великої білої порід: відповідно - 41,2-39,2 та 43,3-42,3 \%. В кількісному вигляді м'яса в тушах було на рівні 32,436,0 кг при забої в 100 кг і 39,8-43,9 кг при забої в 125 кг. Різниця в кількості кісток в тушах була незначною. Коефіцієнт співвідношення сала до м'яса за рахунок сильного оса- лення туш був високим, особливо, у тварин миргородської породи 0,87-0,95. Найменша кількість сала по відношенню до м'яса була у тварин породи ландрас і червоної білопоясної. При збільшенні середньодобових приростів до 600-800 г спостерігалось збільшення кількості м'яса в тушах. Так, в тушах свиней полтавської м'ясної породи, забитих живою масою 100 кг, було 44,1 кг м'яса, або 60,3 \%; забитих живою масою 125 кг - 53,7 кг або 59,1\%. Вихід сала в тушах був на рівні від 28,1-29,4 \% у свиней червоної білопоясної породи до 33,4-36,7 \% у миргородських аналогів.

\section{Морфологічний склад туш піддослідних свиней}

(середньодобовий приріст 600-800 г, n=15)

\begin{tabular}{|c|c|c|c|c|c|c|c|c|c|c|c|c|c|c|c|}
\hline \multirow{4}{*}{ 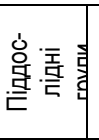 } & \multirow{4}{*}{$\begin{array}{l}\text { 항 } \\
\text { 응 } \\
\text { 단 }\end{array}$} & \multicolumn{12}{|c|}{ Міститься в туші, \% } & \multirow{2}{*}{\multicolumn{2}{|c|}{$\begin{array}{c}\text { Співвідношення сала } \\
\text { до м'яса }\end{array}$}} \\
\hline & & \multicolumn{4}{|c|}{ М'ясо } & \multicolumn{4}{|c|}{ Сало } & \multicolumn{4}{|c|}{ Кістки } & & \\
\hline & & \multicolumn{2}{|c|}{100 кг } & \multicolumn{2}{|c|}{$125 \mathrm{kг}$} & \multicolumn{2}{|c|}{$100 \mathrm{kг}$} & \multicolumn{2}{|c|}{$125 \mathrm{kг}$} & \multicolumn{2}{|c|}{100 кг } & \multicolumn{2}{|c|}{$125 \mathrm{kг}$} & $100 \mathrm{kr}$ & $125 \mathrm{k \Gamma}$ \\
\hline & & $\mathrm{K \Gamma}$ & $\%$ & $\mathrm{k \Gamma}$ & $\%$ & $\mathrm{K \Gamma}$ & $\%$ & Кг & $\%$ & $\mathrm{K \Gamma}$ & $\%$ & $\mathrm{K \Gamma}$ & $\%$ & & \\
\hline I & BБ & $\begin{array}{c}40,7 \pm \\
0,62\end{array}$ & 57,9 & $\begin{array}{c}49,9 \pm \\
0,66\end{array}$ & 55,8 & $\begin{array}{c}21,4 \pm \\
0,61\end{array}$ & 30,4 & $\begin{array}{c}29,4 \pm \\
0,31\end{array}$ & 32,9 & $\begin{array}{l}8,2 \pm \\
0,38\end{array}$ & 11,7 & $\begin{array}{c}10,1 \pm \\
0,33\end{array}$ & 11,3 & $\begin{array}{c}0,53 \pm \\
0,12\end{array}$ & $\begin{array}{c}0,59 \pm \\
0,22\end{array}$ \\
\hline II & M & $\begin{array}{c}38,0 \pm \\
0,29\end{array}$ & 55,2 & $\begin{array}{c}46,1 \pm \\
0,36\end{array}$ & 52,5 & $\begin{array}{c}23,0^{*} \pm \\
0,22\end{array}$ & 33,4 & $\begin{array}{c}32,3^{* *} \pm \\
0,29\end{array}$ & 36,7 & $\begin{array}{l}7,9 \pm \\
0,29\end{array}$ & 11,4 & $\begin{array}{l}9,5 \pm \\
0,29\end{array}$ & 10,8 & $\begin{array}{c}0,61 \pm \\
0,22\end{array}$ & $\begin{array}{c}0,70 \pm \\
0,13\end{array}$ \\
\hline III & Л & $\begin{array}{c}43,8^{* *} \pm \\
0,35\end{array}$ & 60,3 & $\begin{array}{c}54,1^{*} \pm \\
0,61\end{array}$ & 59,1 & $\begin{array}{c}20,5 \pm \\
0,19 \\
\end{array}$ & 28,2 & $\begin{array}{c}27,3^{\star *} \pm \\
0,22 \\
\end{array}$ & 29,8 & $\begin{array}{l}8,3 \pm \\
0,55\end{array}$ & 11,5 & $\begin{array}{c}10,2 \pm \\
0,59 \\
\end{array}$ & 11,1 & $\begin{array}{c}0,47 \pm \\
0,13\end{array}$ & $\begin{array}{c}0,50 \pm \\
0,31 \\
\end{array}$ \\
\hline IV & ПМ & $\begin{array}{c}44,1^{* *} \pm \\
0,45\end{array}$ & 59,9 & $\begin{array}{c}53,7^{*} \pm \\
0,29\end{array}$ & 58,3 & $\begin{array}{c}21,0 \pm \\
0,28 \\
\end{array}$ & 28,5 & $\begin{array}{c}28,1 \pm \\
0,16\end{array}$ & 30,5 & $\begin{array}{l}8,5 \pm \\
0,16\end{array}$ & 11,6 & $\begin{array}{c}10,3 \pm \\
0,34 \\
\end{array}$ & 11,2 & $\begin{array}{c}0,48 \pm \\
0,31\end{array}$ & $\begin{array}{c}0,52 \pm \\
0,41\end{array}$ \\
\hline V & ЧБП & $\begin{array}{c}43,1^{* *} \pm \\
0,62\end{array}$ & 60,5 & $\begin{array}{c}53,4^{*} \pm \\
0,55\end{array}$ & 59,5 & $\begin{array}{c}20,0 \pm \\
0,55\end{array}$ & 28,1 & $\begin{array}{c}26,4 \pm \\
0,35\end{array}$ & 29,4 & $\begin{array}{l}8,1 \pm \\
0,34\end{array}$ & 11,4 & $\begin{array}{c}10,0 \pm \\
0,56\end{array}$ & 11,1 & $\begin{array}{c}0,46 \pm \\
0,19\end{array}$ & $\begin{array}{c}0,49 \pm \\
0,19\end{array}$ \\
\hline
\end{tabular}

Таблиця 3

\section{Морфологічний склад туш піддослідних свиней} (середньодобовий приріст 800-1000 г, n=15)

\begin{tabular}{|c|c|c|c|c|c|c|c|c|c|c|c|c|c|c|c|}
\hline \multirow{4}{*}{ 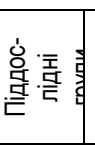 } & \multirow{4}{*}{$\begin{array}{l}\text { 항 } \\
\text { 응 }\end{array}$} & \multicolumn{12}{|c|}{ Міститься в туші, \% } & \multirow{2}{*}{\multicolumn{2}{|c|}{$\begin{array}{c}\text { Співвідношення сала } \\
\text { до м'яса }\end{array}$}} \\
\hline & & \multirow{2}{*}{\multicolumn{4}{|c|}{ М'яco }} & \multicolumn{4}{|c|}{ Сало } & \multicolumn{4}{|c|}{ Кістки } & & \\
\hline & & & & & & \multicolumn{2}{|c|}{$100 \mathrm{kr}$} & \multicolumn{2}{|c|}{$125 \mathrm{kr}$} & \multicolumn{2}{|c|}{$100 \mathrm{kг}$} & \multicolumn{2}{|c|}{$125 \mathrm{Kг}$} & \multirow[t]{2}{*}{$100 \mathrm{kr}$} & \multirow[t]{2}{*}{$125 \mathrm{kr}$} \\
\hline & & KГ & $\%$ & KГ & $\%$ & KГ & $\%$ & KГ & $\%$ & $\mathrm{K \Gamma}$ & $\%$ & $\mathrm{K \Gamma}$ & $\%$ & & \\
\hline I & ВБ & $\begin{array}{c}41,8 \pm \\
0,56\end{array}$ & 58,2 & $\begin{array}{c}51,6 \pm \\
0,31\end{array}$ & 56,8 & $\begin{array}{c}21,7 \pm \\
0,25\end{array}$ & 30,2 & $\begin{array}{c}28,9 \pm \\
0,25\end{array}$ & 31,8 & $\begin{array}{l}8,3 \pm \\
0,35\end{array}$ & 11,6 & $\begin{array}{c}10,4 \pm \\
0,45\end{array}$ & 11,4 & $\begin{array}{c}0,52 \pm \\
0,12\end{array}$ & $\begin{array}{c}0,56 \pm \\
0,22\end{array}$ \\
\hline ॥ & M & $\begin{array}{c}39,7 \pm \\
0,61\end{array}$ & 56,3 & $\begin{array}{c}48,2 \pm \\
0,49\end{array}$ & 53,6 & $\begin{array}{c}23,2^{* * *} \pm \\
0,32\end{array}$ & 32,8 & $\begin{array}{c}32,0^{* *} \pm \\
0,16\end{array}$ & 35,6 & $\begin{array}{l}7,7 \pm \\
0,51\end{array}$ & 10,9 & $\begin{array}{l}9,7 \pm \\
0,33 \\
\end{array}$ & 10,8 & $\begin{array}{c}0,58 \pm \\
0,23 \\
\end{array}$ & $\begin{array}{c}0,66 \pm \\
0,17\end{array}$ \\
\hline III & Л & $\begin{array}{c}44,9^{\star \star} \pm \\
0,34\end{array}$ & 60,9 & $\begin{array}{c}55,5^{\star *} \pm \\
0,55\end{array}$ & 59,6 & $\begin{array}{c}20,5 \pm \\
0,19\end{array}$ & 27,8 & $\begin{array}{c}27,3 \pm \\
0,24\end{array}$ & 29,3 & $\begin{array}{l}8,3 \pm \\
0,26\end{array}$ & 11,3 & $\begin{array}{c}10,3 \pm \\
0,66\end{array}$ & 11,1 & $\begin{array}{c}0,46 \pm \\
0,22\end{array}$ & $\begin{array}{c}0,49 \pm \\
0,16\end{array}$ \\
\hline IV & ПМ & $\begin{array}{c}44,1^{* *} \pm \\
0,19\end{array}$ & 60,2 & $\begin{array}{c}55,1^{*} \pm \\
0,17\end{array}$ & 59,1 & $\begin{array}{c}20,7 \pm \\
0,29\end{array}$ & 28,3 & $\begin{array}{c}27,8 \pm \\
0,16\end{array}$ & 29,8 & $\begin{array}{l}8,4 \pm \\
0,31\end{array}$ & 11,5 & $\begin{array}{c}10,4 \pm \\
0,43\end{array}$ & 11,1 & $\begin{array}{c}0,47 \pm \\
0,16\end{array}$ & $\begin{array}{c}0,50 \pm \\
0,23\end{array}$ \\
\hline V & ЧБП & $\begin{array}{c}44,4^{*} \pm \\
0,37\end{array}$ & 61,4 & $55,2^{* *} \pm 0,31$ & 60,3 & $\begin{array}{c}19,9 \pm \\
0,17\end{array}$ & 27,5 & $\begin{array}{c}26,5 \pm \\
0,35 \\
\end{array}$ & 28,9 & $\begin{array}{l}8,0 \pm \\
0,33\end{array}$ & 11,1 & $\begin{array}{l}9,9 \pm \\
0,38\end{array}$ & 10,8 & $\begin{array}{c}0,45 \pm \\
0,31\end{array}$ & $\begin{array}{c}0,48 \pm \\
0,12\end{array}$ \\
\hline
\end{tabular}


При збільшенні забійної маси до 125 кг питома маса кісток в тушах зменшувалась в усіх піддослідних групах на 0,3-0,6 \%. Відмічалось зменшення відношення сала до м'яса в межах 0,46-0,61 при забої в 100 кг і 0,49-0,70 - в 125кг.

Слід відмітити, що збільшення середньодобових приростів на відгодівлі до 800-1000 г сприяло збільшенню виходу м'яса в тушах в порівнянні з тушами свиней середнього рівня годівлі. Різниця між тушами свиней в 100 кг дорівнювала 1,1-1,7 \%; при збільшенні забійної маси різниця склала 1,4-2,1\%.

Найбільший вихід м'яса спостерігався у тварин чер- воної білопоясної породи 61,4 \% в 100 кг і 60,3 \% в 125 кг. Збільшення виходу м'яса вело до зменшення виходу сала в усіх групах до 27,5-32,8 \% в 100 кг і 28,9-35,6 \% в 125 кг. Дисперсійний аналіз впливу рівня годівлі на вміст м'яса в тушах показав, що коефіцієнт детермінації, тобто питома вага факторіальної дисперсії в загальній, найбільшим був у свиней породи ландрас 0,893-0,896, що відповідно і визначило найбільшу залежність в показниках вмісту м'яса цих тварин від рівня годівлі (таблиця 4,5). Найменше фактор годівлі впливав на вихід м'яса в тушах миргородської породи.

Таблиця 4

Дисперсійний аналіз впливу рівня годівлі на вміст м'яса в тушах свиней (n=15)

\begin{tabular}{|c|c|c|c|c|c|c|c|c|c|c|c|c|c|c|c|c|c|c|c|c|}
\hline \multirow{5}{*}{ Рівень годівлі } & \multicolumn{20}{|c|}{ Порода } \\
\hline & \multicolumn{4}{|c|}{ BБ } & \multicolumn{4}{|c|}{ M } & \multicolumn{4}{|c|}{$\pi$} & \multicolumn{4}{|c|}{$\mathrm{nM}$} & \multicolumn{4}{|c|}{ पБП } \\
\hline & \multicolumn{2}{|c|}{$100 \mathrm{Kr}$} & \multicolumn{2}{|c|}{$125 \mathrm{kr}$} & \multicolumn{2}{|c|}{$100 \mathrm{kr}$} & \multicolumn{2}{|c|}{$125 \mathrm{kr}$} & \multicolumn{2}{|c|}{$100 \mathrm{kr}$} & \multicolumn{2}{|c|}{$125 \mathrm{kr}$} & \multicolumn{2}{|c|}{$100 \mathrm{kr}$} & \multicolumn{2}{|c|}{$125 \mathrm{kr}$} & \multicolumn{2}{|c|}{100 кг } & \multicolumn{2}{|c|}{$125 \mathrm{kr}$} \\
\hline & 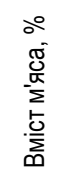 & 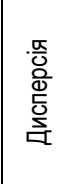 & 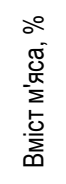 & 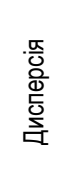 & 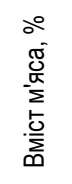 & 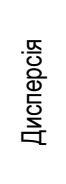 & 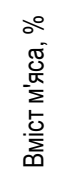 & 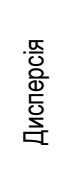 & 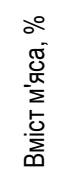 & 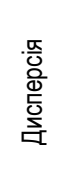 & 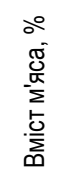 & 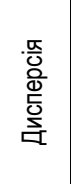 & 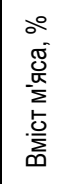 & 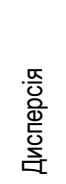 & 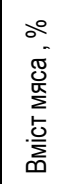 & 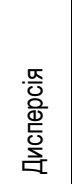 & 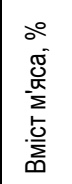 & 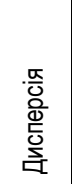 & 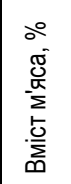 & 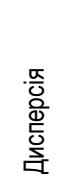 \\
\hline & $\mathrm{x}_{\mathrm{i}}$ & $\sigma_{s}{ }^{2}$ & $x_{i}$ & $\sigma_{s}{ }^{2}$ & $x_{i}$ & $\sigma_{s}{ }^{2}$ & $x_{i}$ & $\sigma_{s}{ }^{2}$ & $x_{i}$ & $\sigma_{s}{ }^{2}$ & $x_{i}$ & $\sigma_{s}{ }^{2}$ & $x_{i}$ & $\sigma_{s}{ }^{2}$ & $x_{i}$ & $\sigma_{s}{ }^{2}$ & $x_{i}$ & $\sigma_{s}{ }^{2}$ & $x_{i}$ & $\sigma_{s}{ }^{2}$ \\
\hline Типовий & 48,9 & 3,31 & 46,3 & 2,36 & 47,3 & 3,25 & 45,8 & 0,92 & 50,1 & 1,27 & 48,6 & 1,99 & 48,7 & 2,22 & 47,1 & 4,23 & 50,6 & 3,78 & 48,9 & 1,98 \\
\hline Середній & 40,7 & 3,35 & 49,9 & 3,69 & 38,0 & 2,85 & 46,1 & 0,22 & 43,8 & 1,11 & 54,1 & 0,41 & 44,1 & 2,77 & 53,7 & 3,15 & 43,1 & 3,65 & 53,4 & 1,53 \\
\hline Інтенсивний & 41,8 & 3,41 & 51,6 & 2,0 & 39,7 & 2,96 & 48,2 & 0,66 & 44,9 & 0,34 & 55,5 & 0,68 & 44,1 & 2,11 & 55,1 & 2,99 & 44,4 & 4,65 & 55,2 & 0,98 \\
\hline $\begin{array}{l}\text { В середньому за } \\
\text { дослідом }\end{array}$ & 43,8 & 3,36 & 49,3 & 2,68 & 41,7 & 3,02 & 46,7 & 0,60 & 46,3 & 0,91 & 52,7 & 1,03 & 45,6 & 2,37 & 52,0 & 3,46 & 46,0 & 4,03 & 52,5 & 1,50 \\
\hline
\end{tabular}

Результати дисперсійного аналізу

Таблиця 5

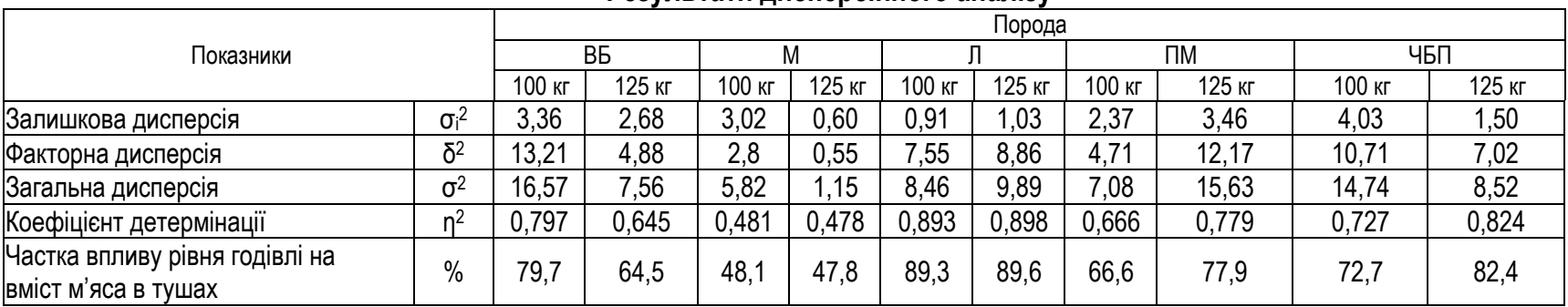

Результати наукових розробок свідчать, що м'ясну свинину як високоякісний продукт можна одержати із туш молодняку інтенсивно відгодованого до 90-100 кг живої маси (при середньодобових приростах 600 г і більше, витраті на 1кг приросту не більше 4 корм. од.). При цьому забезпечується вихід 55-58 \% м'яса без кісток і не більше 28-32 \% жиру при середній товщині шпику на спині 2,8-3 см. Саме така свинина найбільше відповідає вимогам м'ясопереробної промисловості та споживача. Одержати свиней із максимальною м'ясністю туш можна, в першу чергу, шляхом систематичної селекції за цією ознакою. Велике значення при проведенні селекції на м'ясність має знання методів оцінки м'ясо-сальних якостей свиней [3].

Аналіз досліджень показує, що площа «м'язового вічка» у тварин всіх піддослідних груп значно коливалась. При типовому рівні годівлі від 23,1 до 29,2 см² в 100 кг і від 24,7 до 31,6 см² в 125 кг. При середньому рівні годівлі для більшості підсвинків площа «м'язового вічка» істотно збільшувалась: при забої в 100 кг вона дорівнювала від 27,2 см² у

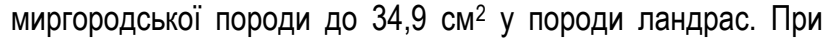
збільшенні забійної маси до 125 кг площа «м'язового вічка» в тушах цих порід склала відповідно 28,3 і 37,4 см². Аналогі- чна ситуація спостерігалась і у тварин, відгодованих при середньодобових приростах 800-1000 г. Найбільшою площа «м'язового вічка» була у свиней породи ландрас - 35,8-36,7 $\mathrm{cm}^{2}$, найменшою у тварин миргородської породи - 27,7-28,4 $\mathrm{cm}^{2}$. Свині великої білої породи за цим показником були близькі до миргородської породи, а полтавської м'ясної і червоної білопоясної до породи ландрас.

Відношення площі «м'язового вічка» до площі підшкірного сала, що прилягає до нього, як відомо, має назву індексу м'ясності. Він дає змогу визначити співвідношення м'яса та сала в туші. Саме індекс м'ясності був найбільшим у тварин м'ясних генотипів .

Спостерігалась пряма залежність між середньодобовими приростами піддослідних свиней і індексом м'ясності. Збільшення площі «м'язового вічка» в групах тварин, вирощених з більш високими середньодобовими приростами вело до збільшення індексу м'ясності. При інтенсивному рівні відгодівлі він був на рівні 0,91-1,13 в тушах свиней забитих в 100 кг і 0,88-1,09 - забитих в 125 кг. Що стосується міжпородних розбіжностей, то найбільший індекс м'ясності мали свині породи ландрас при всіх рівнях відгодівлі. 
Установлено, що м'ясність туш висока, якщо індекс її більший одиниці. Кореляція між виходом м'яса в туші та площею «м'язового вічка» знаходиться в межах 0,45-0,46, виходом м'яса та площею сала - 0,5 - 0,6, а виходом м'яса та індексом м'ясності - 0,55-0,77 [3].

Індекс м'ясності туш більше одиниці спостерігався у свиней породи ландрас, полтавська м'ясна, червоної білопоясної при середньому та інтенсивному рівнях годівлі. При середньодобових приростах 250-350 г індекс м'ясності в усіх групах був менше одиниці, що підтверджує отримані раніш дані.

Найвищою енергетичною цінністю характеризувалося м'ясо тварин м'ясо-сальних і сальних генотипів (I та II групи). При типовому рівні відгодівлі калорійність їх м'яса становила в середньому 134,9-135,8 ккал при забої у 100 кг і 141,5-144,2 ккал - у 125 кг, що відповідно на 8,1-9,0 та 11,113,8 ккал більше в порівнянні з представниками породи ландрас, де цей показник був найменшим. При збільшенні середньодобових приростів спостерігалось зменшення калорійності м'яса. Найменшою вона спостерігалась у свиней, вирощених при інтенсивному рівні відгодівлі: 116,2124,4 ккал при забої в 100 кг і 122,4-135,2 ккал при забої в 125 кг.

Висновки. При середньодобових приростах 250-350 г за рахунок низьких приростів і, як правило, більшого при цьому осалення, вихід м'яса у тварин всіх піддослідних груп був низьким. Збільшення середньодобових приростів на відгодівлі до 800-1000 г сприяло збільшенню виходу м'яса в тушах порівняно з тушами свиней, вирощених при оптимальних умовах. Різниця між тушами свиней в 100 кг дорівнювала 1,1-1,7 \%; при збільшенні забійної маси різниця склала 1,4-2,1\%. Дисперсійний аналіз впливу рівня годівлі на вміст м'яса в тушах показав, що коефріцієнт детермінації, тобто питома вага фракторіальної дисперсії

\section{Список використаної літератури:}

1. Акімов С. Основні напрями подальшої роботи по вдосконаленню свиней полтавської та української м'ясних порід. Тваринництво України. 2002. № 5, С. 23-24.

2. Баньковська І. Б., Волощук В. М. Вплив різних способів утримання свиней на якість туш. Тваринництво України. 2014. № 10, С. 21-23.

3. Бирта Г. А., Бургу Ю. Г., Моторный Ю. В. Мясные качества свиней разных генотипов в зависимости от влияния на них паратипических факторов. Вісник Полтавської державної аграрної академії. 2008. № 4, С. 106-110.

4. Волощук В.М. Свинарство: монографія - Київ: Аграрна наука, 2014, 592 с.

5. Волощук В.М. Тенденции, современное состояние и стратегия ведения свиноводства в Украине. Инновационные пути разведения АПК: Проблемы и перспективы. - Персиановка. 2013. С. 26-30.

6. Рибалко В. П., Березовський М. Д. , Богданов Г. А. [та ін.]. Сучасні методики досліджень у свинарстві. Полтава: Інститут свинарства ім. О.В. Квасницького УААН, 2005. 228 с.

7. Рибалко В. П., Висланько О.О.Порівняльне вивчення репродуктивних, відгодівельних та м'ясних якостей свиней різного напрямку продуктивності. Вісник аграрної науки. 2002. № 8. С.28-32.

8. Сердюк О. Ефективність застосування різних типів годівлі при вирощуванні молодняка свиней червоно-поясної спеціалізованої лінії. Збірник Наукових праць Вінницького національного аграрного університету. Серія: Сільськогосподарські науки. 2001. № 9, С. 124-125.

9. Топіха В., Волков А. Інтенсивне ведення галузі свинарства. Твариниитво України. 2003. №8, С. 2-4.

10. The significance of the effects influencing the reproductive performance in pigs / M. Šprysl, J. Čítek, R. Stupka [et al.] // Research in pig breeding. 2012. Vol. 6(1), P. 54-58.

11. Brent G. The Pigman's Handbook of Problem Solving / Gerry Brent., 2010. 192p. (Crowood Press; 1 edition).

\section{References:}

1. Akimov S., 2002. Osnovni napriamy podalshoi roboty po vdoskonalenniu svynei poltavskoi ta ukrainskoi miasnykh porid. Tvarynnytstvo Ukrainy, no. 5, pp. 23-24.

2. Bankovska, I. B. and Voloshchuk, V. M., 2014. Vplyv riznykh sposobiv utrymannia svynei na yakist tush [Influence of different ways of keeping pigs on the quality of carcasses]. Tvarynnytstvo Ukrainy, no. 10, pp. 21-23.

3. Birta, G. A., Burgu, Yu. G. and Motornyy, Yu. V., 2008. Myasnye kachestva sviney raznykh genotipov v zavisimosti ot vliyaniya na nikh paratipicheskikh faktorov [Meat qualities of pigs of different genotypes, depending on the influence of paratypical factors on them]. Visnik Poltavs'koï derzhavnoï agrarnoï академії, no. 4, pp. 106-110.

4. Voloshchuk V.M., 2014. Svynarstvo: monohrafiia. Kyiv: Ahrarna nauka.

5. Voloshchuk V.M., 2013. Tendentsyy, sovremennoe sostoianye y stratehyia vedenyia svynovodstva v Ukrayne [Innovatsionnyie puti razvedeniya APK: Problemyi i perspektivyi]. Persyanovka. pp.26-30.

6. Rybalko, V. P., Berezovskyi, M. D., Bohdanov, H. A. [et al.], 2005. Suchasni metodyky doslidzhen u svynarstvi [Modern research methods in pig breeding]. Poltava: Instytut svynarstva im. O.V.Kvasnytskoho UAAN.

7. Rybalko V.P., 2002. Porivnialne vyvchennia reproduktyvnykh, vidhodivelnykh ta miasnykh yakostei svynei riznoho napriamku produktyvnosti [Rybalko V.P., Vyslanko 0.0.]. Visnyk ahrarnoi nauky, no 8. pp.28-32.

8. Serdiuk O., 2001. Efektyvnist zastosuvannia riznykh typiv hodivli pry vyroshchuvanni molodniaka svynei chervonopoiasnoi spetsializovanoi linii. Zbirnyk Naukovykh prats Vinnytskoho natsionalnoho ahrarnoho universytetu. Seriia: Silskohospodarski nauky, no. 9, pp. 124-125.

9. Topikha V., 2003. Intensyvne vedennia haluzi svynarstva. Tvarynytstvo Ukrainy, no.8, pp. 2-4.

10. The significance of the effects influencing the reproductive performance in pigs / M. Šprysl, J. Čitek, R. Stupka [et al.] // Research in pig breeding. 2012. Vol. 6(1), P. 54-58. 
11. Brent G. The Pigman's Handbook of Problem Solving / Gerry Brent., 2010. 192p. (Crowood Press; 1 edition).

Birta Habriella Oleksandrivna, Doctor of Agricultural Sciences, Professor

Burhu Yurii Georgiyovich, Ph.D. of Agricultural Sciences, Associate Professor

Floka Liudmyla Valerievna, Ph.D. of Agricultural Sciences, Associate Professor

Ukoopspilka Higher Educational Institution "Poltava University of Economics and Trade" (Poltava, Ukraine)

Morphological composition and meat and fat qualities of pig carcasses

The meat content of carcasses at different levels of feeding of pigs of large white, Myrhorod, Landrace, Poltava meat, red white-belt breeds was studied. The morphological composition of carcasses was studied by deboning the right carcass. Muscle mass was determined by the difference between the weight of the carcass and the total weight of fat and bone. The area of the "muscle eye" was measured in the lumbar section of the longest muscle of the back, between the last thoracic and the first lumbar vertebrae by copying the "pattern of the log" on the tracing paper and measuring it with a planimeter. The results of deboning the carcasses of experimental pigs of the first series of studies indicate that the morphological composition of the carcass depends on the breed characteristics of the animals. At an average daily gain of 250-350 g due to low gains and, as a rule, higher salinity, meat yield in animals of all experimental groups was low. At the same time, the red meat of the white-belt breed had the highest meat yield: at slaughter at $100 \mathrm{~kg}-50.6 \%$, at slaughter at $125 \mathrm{~kg}-48.9 \%$. With the increase of carcass weight to $125 \mathrm{~kg}$, the specific weight of bones in carcasses decreased in all experimental groups by $0.3-0.6 \%$. There was a decrease in the ratio of lard to meat in the range of 0.46-0.61 at slaughter in $100 \mathrm{~kg}$ and 0.49-0.70 in $125 \mathrm{~kg}$. Increasing the average daily gain on fattening to 800-1000 $\mathrm{g}$ contributed to an increase in meat yield in carcasses compared to carcasses of medium-fat pigs. The difference between the carcasses of pigs per $100 \mathrm{~kg}$ was 1.1-1.7\%; with increasing carcass weight, the difference was 1.4-2.1\%. The highest energy value was characterized by meat of meat-fat and fat genotypes (groups I and II). At a typical level of fattening, the caloric content of their meat averaged 134.9-135.8 kcal at slaughter per $100 \mathrm{~kg}$ and $141.5-144.2 \mathrm{kcal}$ at $125 \mathrm{~kg}$, which is $8.1-9.0$ and 11.1-13.8 kcal more than the representatives of the Landrace breed, where this figure was the lowest. As the average daily gain increased, so did the caloric content of the meat. It was lowest in pigs raised at intensive fattening levels. Thus, at an average daily gain of 250-350 g due to low gains and, as a rule, higher salinity, meat yield in animals of all experimental groups was low. Increasing the average daily gain on fattening to 800-1000 $\mathrm{g}$ contributed to an increase in meat yield in carcasses compared to carcasses of pigs raised under optimal conditions. The difference between the carcasses of pigs per $100 \mathrm{~kg}$ was 1.1-1.7\%; with increasing carcass weight, the difference was 1.4-2.1\%. Analysis of variance of the effect of the level of feeding on the meat content in carcasses showed that the coefficient of determination, ie the proportion of factorial dispersion

Key words: breed, meat, fat, bones, feeding level, average daily gain, carcass weight, carcass, meat yield.

Дата надходження до редакції: 02. 12.2020 р. 